下顎骨，頭蓋骨および肺にみられた好酸球肉芽腫の 1 例 水城春美・平野公彦・小泉堅・福山義邦

\title{
A case of eosinophilic granuloma in the mandible, the skull and the lung
}

\author{
Harumi Mizuki - Kimihiko Hirano $\cdot$ Ken Korzumi \\ Yoshikuni FukuYama
}

\begin{abstract}
Key words: eosinophilic granuloma (好酸球肉芽腫), mandible (下顎), skull (頭蓋), lung (肺), multifocal (多発性)
\end{abstract}

\section{緒言}

好酸球肉芽腫 (esinophilic granuloma, 以下 EG) の 臨床像は多彩で, 単発性㐫るいは多発性骨病巣の活か尿 崩症の合併や眼球突出, 皮覤, リンパ節, 肺などでの発 現が認められている。われわれは，下顎骨，頭蓋骨抢よ び肺に発症が認められた EGの1 例を経験したので報告 する.

\section{症例}

患 者: 35歳 男性 外国航路船員.

初 診：1982年（昭和 57 年） 9 月回。

主 訴: 左下顎目歯部頪側歯肉の有痛性腫脹.

家族歴・既往歴：特記すべきことなし。

現病歴：10か月前, 症状が初発. 近歯科飞て切開排膿 処置を受け, 症状は消退, 7 か月前, 症状再発. 消炎処 置招よび 15 の抜歯を受けるも，疼痛持続するため某病 院歯科を受診し, 慢性骨䯣炎の診断のもと $\sqrt{5}$ 拔歯窩再 搔爬，骨切除術を受けた。.以後の治療の継続を希望して 当科を受診した。

現 症：口腔外所見では顔貌は左右対称性で, 眼球突 出はなかった。

口腔内所見では 5678 は欠損し, 頓側歯肉に軽度の腫 脹, 圧痛が認められた。

初診時検查成績 : $\mathrm{X}$ 線写真で, $\overline{1 \uparrow 7}$ 相当部の骨体飞不 規則な骨透過像が認められ, 血液検查成績では白血球数 增多, GPT 軽度上昇, 血沈元進, CRP 陽性がみられ た.

\section{大分医科大学菌科口腔外科学教室}

（主任：清水正嗣教授）

Department of Oral and Maxillo-Facial Surgery, Oita Medical University (Chief: Prof. Masatsugu Shimizu)

受付日：平成 4 年 4 月 13 日

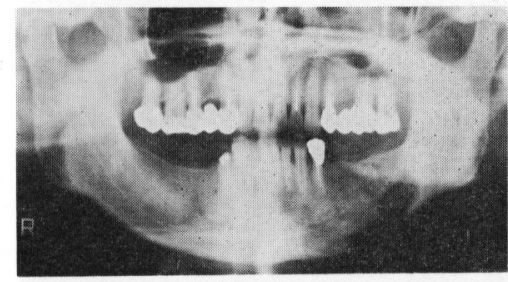

写真 1 初診後約 1 年の再来時(下顎骨病巣 第 1 回手術前）パントモ X線写真

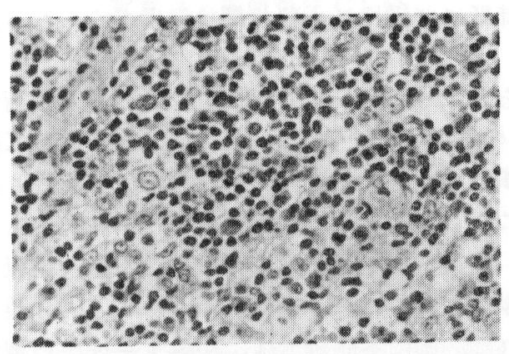

写真 2 下顎骨病巣の生㭘組織の病理組織 像 $(\mathrm{H}-\mathrm{E}$ 染色，原倍率 $\times 200)$

処置および経過：当初，前医による慢性骨䯣炎との病 理組織診断に従い，経過観察を行っていたが，8か月間 航海のため通院が中断された。初診から約 1 年後の再来 時, X線写真では骨吸収像の拡大が羿められた（写真 1). 同部の生検を行ったところ, リンパ球, 好酸球お よび組織球の混在した肉芽組織がみられ, 好酸球肉芽腫 と診断された（写真 2).1983 年 10 月, 全身麻酔下に肉 芽腫摘出搔爬術を施行した。 術後経過は順調であった が, 手術から9 か月後の再来時のX線検查にて下䫇前歯 部, 左骨体後方部および下顎枝部に骨吸収像を認めた。 肉芽腫の再発々診断 L, 1984年 9 月， 2 回目の摘出搔爬 術を施行した。病理組織所見は前回と同様であった。さ らにその10か月後のX線検査で, 左筋突起部に骨吸収像 


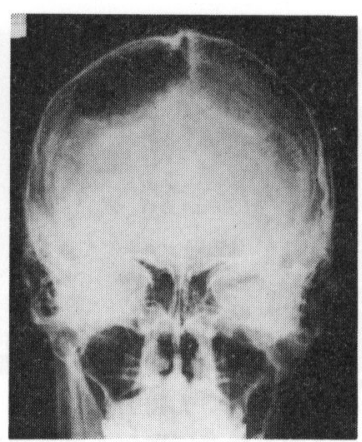

写真 3 頭蓋骨病覓摘出術前の頭部 $\mathrm{X}$ 線写真

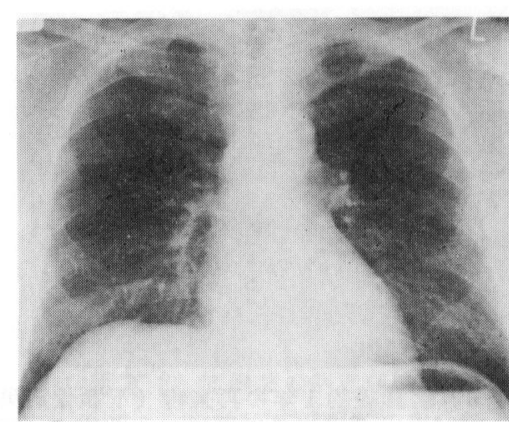

写真 4 経気管支肺生検施行時の胸部 $\mathrm{X}$ 線写真 画肺野にび慢性に小粒状網状院影がみられる。

が認められたため, 1985 年 9 月に 3 回目の手術を行っ た. その後, 1987 年 3 月の再来時撮影の頭部 X線写真 で，右頭頂部に骨欠損像が認められた（写真3）ため, 脳外科に対診。頭蓋骨の好酸球肉芽腫の診断のもと, 同 年 6 月, 病巣全摘, 頭蓋形成術が施行され, 術後 $20 \mathrm{~Gy}$ の放射線が照射された。摘出組織は好酸球肉芽腫と病理 診断された。 また本症例では, 初診 1 年後から胸部X線 写真にてび漫性微細粒状網状陰影がみられていたが, 1987 年同陰影の増強が認められた（写真 4). 内科にて 経気管支肺生検が行われ, 肺好酸球肉芽腫と診断, ステ ロイド療法が行われた。しかしあきらかな効果なく，漸 減中止となった。 な拝数回行った骨シンチグラムで, 下
顎，頭頂部以外の骨にも集積がみられたが，整形外科で の診察では下顎骨，頭蓋骨以外の他部位にあきらかな病 巣は認められなかった。下顎骨の第 3 回手術後 6 年の所 見では顎骨, 頭蓋骨病巣の再発はなく, 胸部X線所見に 著変はみられず，また他部位での新たな病巣の発現も認 められていない。

\section{考察}

本症例は慢性播種性の histiocytosis X (HX) に該当 するが，眼球突出揖よび尿崩症はなくHand-SchüllerChristian 病とはいいがたい. Groopman ら² は HX を unifocal EG, multifocal EG 物よび diffuse histiocytosis of Letterer-Siwe type に分類しているが，これに従壳ば 本症例は multifocal EG に属するものと思われる。 EG は肺での発現もみられる が, 本邦の口腔外科領域の報 告例には肺病変の合併例はきわめて少なく, その数は顎 骨好酸球肉芽腫として報告された 30 数例中, 自験例を含 めわずかに 4 例のようである

ご指導，ご校閲を載きました清水正嗣教授に感謝申し 上け゚ます。

な招本論文の要旨は, 第59回日本口腔外科学会九州地 方部会（1992年 2 月 8 日, 鹿児島）飞拈いて発表した。

\section{引用文 献}

1) Groopman, J.E., and Golde, D.W.: The histiocytic disorders: A pathophysiologic analysis, Ann Intern Med 94: 95-107 1981.

2）伊藤慶夫, 岩井和郎, 他: 本邦に括ける肺好酸 球肉芽腫症の実態について, 日胸疾会誌 21 : 539-547 1983.

3）早津良和, 安達弘高, 他: 下顎骨に発生した eosinophiric granuloma の 2 症例. 日外誌 28: 1254-1259 1982.

4) 柳澤高道, 尾上祐悦, 他 : 胸部X線像に異常陰 影を伴った下顎骨好酸球肉芽腫の 1 例。 日口外 誌 33: 2126-2130 1987.

5）永井格, 京極順二, 他：顎骨, 座骨, 肺に久 られた好酸球肉芽腫の 1 例. 日口外誌 36 : 1096-11031990. 